\title{
Sentimen Investor dan Three-Factor Asset Pricing Model (Studi Empirik di Bursa Efek Indonesia)
}

\author{
William Wendy Ary \\ Fakultas Manajemen dan Bisnis, Universitas Ciputra \\ e-mail: william.wendy@ciputra.ac.id
}

\begin{abstract}
Abstrak
Penelitian ini menginvestigasi peranan sentimen investor terhadap return industri beserta implikasinya pada three-factor asset pricing model. Peranan sentimen investor pada penelitian ini diukur menggunakan proksi Indeks Keyakinan Konsumen (IKK). Penelitian ini menggunakan data bulanan dari Januari 2013 sampai Desember 2017. Hasil penelitian ini membuktikan bahwa sentimen investor berpengaruh negatif terhadap return industri terutama pada sektor properti, real estate, dan konstruksi bangunan dan sektor keuangan, serta membuktikan pengaruh sentimen investor yang signifikan pada model asset pricing, khususnya three-factor asset pricing model. Secara garis besar, peranan sentimen investor yang signifikan tersebut menunjukkan adanya fenomena mispricing dalam melakukan penilaian harga aset di pasar modal Indonesia.
\end{abstract}

Kata Kunci : Sentimen Investor, Asset Pricing, Behavioral Asset Pricing Model (BAPM), Keuangan Keperilakuan

\section{PENDAHULUAN}

Sharpe (1964) dan Lintner (1965) menyatakan bahwa salah satu model penilaian harga aset yang saat ini berkembang pada mulanya berasal dari model Capital Asset Pricing Model (CAPM). CAPM selalu berasumsi bahwa beta selalu konstan sepanjang waktu. Tentu saja asumsi tersebut tidak selalu dapat dijadikan sebagai sebuah acuan untuk menilai harga aset karena beta saham selalu berubah sepanjang waktu. Kelemahan yang ada di dalam model CAPM telah menarik perhatian beberapa peneliti yang mencoba berkontribusi untuk mengurangi kelemahan pada model CAPM.

Beberapa karakter spesifik perusahaan tersebut adalah ukuran perusahaan (Banz, 1981; Chan and Chen, 1988), earnings yield (Ball, 1978; Basu, 1977), book-to-market ratio (Fama and French, 1992; Rossenberg et al., 1977), dividend yield (Litzenberg and Ramaswamy, 1979), dan leverage perusahaan (Bhandari, 1988). Kritik terhadap keakuratan CAPM juga mendorong Fama dan French untuk memunculkan three-factor asset pricing model sebagai model yang dianggap pada saat itu sebagai model asset pricing yang lebih baik dari CAPM. Namun, model-model asset pricing yang berkembang hingga saat ini menggunakan asumsi rasionalitas Bayesian dan expected utility theory yang tentu saja mengabaikan aspek keperilakuan dalam melakukan proses penilaian aset. Penelitian yang mencoba memasukkan aspek keperilakuan telah mendapatkan perhatian yang serius salah satunya adalah menguji peranan sentimen investor dalam model asset pricing.

Penelitian terdahulu selalu melakukan pengujian peranan sentimen investor dalam asset pricing dengan menggunakan namun kurang memperhatikan pengaruhnya jika diteliti dari perspektif industri padahal industri memiliki karakteristik yang sama seperti karakteristik perusahaan yang dapat 
menghasilkan penilaian investasi dan tekanan sentimen investor yang beragam dan berbeda satu sama lain (Sekkat and Valjamets, 2016). Beberapa penelitian mengenai hal tersebut pernah dilakukan namun unit analisisnya menggunakan industri-industri yang beroperasi di negara yang relatif maju seperti Amerika Serikat (Sayim et al., 2013), Republik Rakyat China (Yang and Sheng, 20 14) dan Swedia (Sekkat and Valjamets, 2016) dan jarang menggunakan industri yang ada di negara yang berkembang di wilayah ASEAN seperti Indonesia dan merupakan salah satu negara yang berpotensi masuk sebagai salah satu macan Asia dari segi perekonomiannya (French, 2017). Selain itu, kondisi pasar modal di Indonesia bukanlah pasar yang efisien dan berbentuk quasi rational (Kim and Shamsuddin, 2008; Hoque, Kim, and Pyun, 2007). Dengan kondisi pasar modal yang seperti demikian tentu saja mengindikasikan nilai sebuah perusahaan yang beroperasi pada industri tertentu dibentuk oleh unsur sentimen investor serta peranan sentimen investor mempengaruhi harga saham sebuah perusahaan (Fisher and Statman, 2000; Fisher and Statman, 2004) maupun return industri (Molchanov and Stangl, 2013; Sekkat and Valjamets, 2016).

Penelitian ini hendak membuktikan dua hipotesis utama yaitu: (1) untuk menguji pengaruh sentimen investor terhadap return industri di sebuah negara khususnya sektor-sektor industri yang ada di Indonesia, dan (2) untuk menguji pengaruh sentimen investor di dalam model asset pricing, khususnya pada Fama-French's three-factor asset pricing model. Kedua tujuan penelitian tersebut penting karena dapat mengidentifikasi adanya faktor penilaian secara subjektivitas oleh para investor dalam melakukan valuasi investasi pada beberapa perusahaan yang beroperasi dalam industri-industri di Indonesia yang tentu saja mengindikasikan adanya fenomena mispricing.

\section{TINJAUAN PUSTAKA}

\section{Teori Keuangan Tradisional}

Efficient market hypothesis (EMH) merupakan salah satu teori utama yang ada bidang keuangan dan hingga saat ini selalu didiskusikan oleh para akademisi ilmu ekonomi maupun keuangan. Friedman (1953) mengemukakan pertama kali hipotesisnya yang beranggapan bahwa ketika harga sebuah aset tepat, maka setiap orang tidak akan memperoleh manfaat tambahan dari aktivitas penjualan aset tersebut dan anggapan itu secara sederhana disampaikan dalam kalimat "prices are right, there is no free lunch". Pada dasarnya, pasar efisien merupakan sebuah kondisi pasar sekuritas dimana harga-harga sekuritas yang diperdagangkan telah mencerminkan informasi yang tersedia yanga ada di pasar.

Ada tiga asumsi utama yang mendasari konsep EMH. Pertama, investor diasumsikan berpikir dan bertindak secara rasional dan hal tersebut mengimplikasikan bahwa semua investor yang bertransaksi di pasar modal adalah orang-orang yang berperilaku secara rasional dalam melakukan pengambilan keputusan dalam berinvestasi. Kedua, apabila irrational investor dapat ditemukan di pasar, maka keberadaan mereka acak (random) dan biasanya saling meniadakan serta tidak mempengaruhi nilai fundamental sekuritas yang diperdagangkan di pasar modal. Ketiga, apabila 
keberadaan irrational investor tidak saling berlawanan dan mereka saling bertransaksi pada arah yang sama, maka para arbitrageur memiliki peran untuk untuk menetralkan dan mengurangi pengaruh mereka di pasar. Keabsahan hipotesis pasar efisien mendapatkan pertentangan dari berbagai kalangan akademisi di bidang keuangan salah satunya adalah mengenai perbedaan volatilitas saham dan volatilitas dividen atau revenue emiten-emiten yang ada di pasar dimana volatilitas ternyata memiliki volatilitas yang lebih besar dibandingkan volatilitas dividen atau revenue (Shiller, 1981; Black, 1986). Tantangan terhadap EMH juga berasal dari pembuktian empiris yang mengatakan bahwa harga saham tidak selamanya bergerak dalam sebuah pola yang acak dalam jangka panjang (De Bondt and Thaler, 1985) dan dalam jangka pendek (Bernard and Thomas, 1989; Jegadeesh and Titman, 1993).

\section{Teori Keuangan Keperilakuan}

Ketidakmampuan teori keuangan tradisional menjelaskan fenomena telah membuat beberapa peneliti keuangan beralih kepada bidang ilmu keuangan yang mengakomodasi aspek keperilakuan dan aspek psikologis dalam menjelaskan fenomena-fenomena yang terjadi di pasar keuangan. Hal inilah yang menjadi cikal bakal kemunculan bidang keilmuan keuangan keperilakuan (behavioral finance). Pada dasarnya keuangan keperilakuan mencoba untuk memberikan sebuah pemaparan yang logis mengenai unsur apa, mengapa, dan bagaimana keuangan dan investasi saling berhubungan dengan mengambil sudut pandang sifat dan psikologi dari manusia. Aspek-aspek yang berkaitan dengan keuangan, psikologi, dan sosiologi adalah berbagai aspek yang mampu mempengaruhi proses pengambilan keputusan keuangan oleh individu, kelompok, maupun entitas.

\section{Sentimen Investor}

Beberapa literatur sebelumnya telah menunjukkan bahwa tidak ada konsensus mengenai definisi pasti dari sentimen investor. Definisi umum yang biasanya digunakan berasal dari konsep noise trader (Black, 1986). Dari teori noise trader muncul sejumlah model berbasis perilaku yang telah mencoba untuk menjelaskan pengaruh noise trader dalam menentukan harga saham (De Long, 1990; Shleifer, Summers and Waldman, 1991; Campbell and Kyle, 1993). Ada tiga pendekatan pengukuran yang dapat digunakan untuk mengukur sentimen investor yaitu pengukuran secara langsung (direct measure), pengukuran secara tidak langsung (indirect measure), dan meta measure. Pengukuran langsung dari sentimen investor memiliki satu kelebihan besar. Survei sentimen diukur langsung dengan menanyakan orang tentang harapan mereka terhadap pasar sehingga menghasilkan indikator yang sangat tepat. Namun, memiliki sumber yang mungkin banyak melakukan kesalahan dalam memberikan respon seperti pewawancara, kuesioner atau mungkin respondennya (Groves, 1989). Pengukuran sentimen tidak langsung merujuk ke variabel keuangan dan memerlukan teori yang berkaitan terhadap sentimen. Kelemahan pengukuran tidak langsung terletak pada perlunya membangun teori dan interpretasi masing-masing yang berpotensi membuat hubungan yang pasti 
antara teori dan empirik hilang. Namun, penggunaan pengukuran tidak langsung hingga saat ini sering digunakan pada beberapa literatur karena kemudahan dan sederhana.

\section{Indeks Keyakinan Konsumen (IKK) Sebagai Proksi Pengukuran Sentiman Investor}

Dalam penelitian ini, pengukuran sentimen investor menggunakan pendekatan pengukuran langsung (direct measure). Data yang lazim digunakan dalam pendekatan ini adalah dengan menggunakan Indeks Keyakinan Konsumen (Consumer Confidence Index). Alasan yang mendasari penggunaan data ini karena indeks keyakinan konsumen dan sentimen investor adalah dua hal yang sama dan memiliki keterkaitan yang erat (Fisher and Statman, 2003; Jansen and Nahuis, 2003; Lemmon and Portniaguina, 2006; Ferrer et al., 2016). Selanjutnya, indeks keyakinan konsumen merupakan data indeks yang bertujuan untuk mengetahui keyakinan konsumen mengenai kondisi ekonomi saat ini, yang tercermin dari tingkat konsumsi responden dan ekspektasi konsumen terhadap kondisi perekonomian pada 6 (enam) bulan yang akan datang (Bank Indonesia, 2016).

Metode pengumpulan data yang digunakan oleh Bank Indonesia untuk membuat indeks ini adalah dengan metode survey. Metode survey merupakan metode yang paling mendekati untuk dapat mengkuantifikasi opini dan keyakinan masyarakat mengenai kondisi perekonomian maupun pasar modal di masa yang akan datang dan metode ini adalah metode yang paling baik sebagai proksi sentimen investor karena metode ini secara langsung dapat mengukur ekspektasi para investor (Zhang, 2008). Tingkat keyakinan investor yang tercermin dalam data IKK berwujud dua kondisi yaitu kondisi optimis dan pesimis. Investor disebut optimis apabila indeks diatas angka 100 dan pesimis apabila dibawah 100.

\section{Hipotesis}

\section{Pengaruh Sentimen Investor terhadap Return Industri}

Berdasarkan teori keuangan keperilakuan, dapat diambil sebuah kesimpulan bahwa mispricing tercipta karena misinformed, permintaan-permintaan yang disebabkan bias dan eksogenitas yang tidak dapat diperbaiki oleh arbitrageurs. Sejalan dengan konsep tersebut, peneliti menduga return dipengaruhi oleh shocks terhadap permintaan saham-saham emiten yang mudah digerakkan oleh sentimen investor terutama emiten yang beroperasi di industri yang relatif muda dan masih berpotensi untuk berkembang seperti di Indonesia. Karakteristik industri seperti ini memiliki volatilitas yang tinggi, sangat kompleks untuk dipahami dan dinilai karena memiliki proyek-proyek yang berisiko, ketergantungan yang tinggi pada aset-aset tidak berwujud dan research and development ( $\mathrm{R}$ and $\mathrm{D}$ ), dan memiliki potensi pertumbuhan sehingga sentimen investor memiliki peranan yang lebih besar dari pada industri-industri yang ada di negara maju seperti industri yang ada Amerika Serikat, Britania Raya, Jepang, dan lainnya (Sekkat and Valjamets, 2016). Semakin banyak asumsi yang perlu dibuat dalam melakukan proses valuasi, maka semakin besar pula faktor subjektivitas yang membentuk sentimen investor. 
Realita yang ada di industri saat ini adalah industri terdiri dari perusahaan yang memiliki siklus pertumbuhan yang berbeda, laba historis yang beragam, risiko yang berbeda, ukuran yang berbeda, dan kompleksitas yang berbeda. Industri yang terdiri dari beberapa emiten yang dinilai secara subyektif lebih dipengaruhi oleh sentimen investor daripada industri yang sebagian besar terdiri dari emiten yang stabil dan memiliki riwayat arus kas yang dapat dilacak, siklus pertumbuhan yang moderat, dan kurangnya ruang untuk asumsi yang meningkatkan ketidakpastian. Selain itu, setiap pihak memiliki perspektif arbitrase yang berbeda satu sama lainnya. Hal tersebut sejalan dengan teori yang mengatakan bahwa jenis perusahaan yang memiliki umur yang muda, tidak menguntungkan, mudah berubah dengan prospek pertumbuhan yang tinggi, lebih sulit untuk melakukan arbitrase (D'Avolio, 2002). Karakteristik industri-industri seperti itu lebih rentan terhadap spekulasi dan risiko yang pada akhirnya membatasi proses arbitrase. Proses arbitrase yang terbatas tersebut membuat saham-saham industri tersebut menjadi lebih mahal, melumpuhkan beberapa usaha arbitrase yang dilakukan oleh para arbitrageurs, dan pada akhirnya mencegah harga fundamental sebuah saham kembali ke titik ekuilibrium. Alasan dibalik prediksi hubungan negatif ini juga didasari oleh adanya sanggahan terhadap gagasan sentimen investor yang tinggi menghasilkan peningkatan nilai aset yang kontemporan. Kenaikan sementara harga aset (kenaikan temporer) ini nantinya disesuaikan turun oleh pelaku pasar sehingga menghasilkan hubungan negatif diantara keduanya (Xu and Green, 2012).

Berdasarkan penjelasan di atas, maka hipotesis pertama dalam penelitian ini yaitu:

Hipotesis 1: Sentimen investor berpengaruh negatif terhadap return industri.

\section{Pengaruh Penambahan Sentimen Investor terhadap Three-Factor Asset Pricing Model}

Model asset pricing tradisional menggunakan formula penilaian harga yang menggunakan basis maksimisasi expected utility dan formula tersebut berdasarkan pada penilaian kognitif di situasi yang berisiko. Para agen tersebut menggunakan keputusan rasional didalam mengambil keputusan dengan menggunakan infomasi eksogen yang esensial dan peramalan yang rasional sehingga sentimen atau faktor emosional tidak termasuk didalamnya. Argumen ini didukung oleh pernyataan Pixley (2002) yang mengatakan "Economics ignores passions like greed . . . by transmuting them to allegedly more predictable, less emotional and completely rational motives of self-interest”.

Pendapat ini menduga bahwa para agen ekonomi tersebut membentuk sebuah anggapan (belief) dan mengambil keputusan tidak hanya menggunakan basis evaluasi kognitif sebagai bentuk antisipasi outcomes dan probabilitas sebuah peristiwa yang akan terjadi, tetapi juga menggunakan penilaian afektif dari informasi-informasi yang mereka miliki dan kondisi-kondisi yang menggugah regulatitas aspek emosional. Pada beberapa situasi tertentu, emosi timbul dari informasi mengenai outcomes dan probabilitas. Hal tersebut juga menimbulkan regularitas emosional. Teori keperilakuan menunjukkan bahwa kekuatan emosi yang pesimis meningkat ketika para agen ekonomi menghadapi situasi yang ambigu tetapi emosi yang pesimistis tersebut akan berkurang ketika peristiwa yang 
dihadapinya tersebut sesuai dengan bentuk mentally vivid (Nisbett and Ross, 1980; Einhorn and Hogarth, 1986).

Setiap individu selalu menyesuaikan diri dengan norma sosial sehingga faktor emosi terkadang menjadi pertimbangan seorang individu membuat keputusan. Zafar (2008) menemukan bahwa individu suka menyesuaikan diri dan mendapatkan kesejahteraan emosional hanya dengan membuat keputusan yang identik dengan pola perbandingan sosial yang sudah terlebih dahulu dibuat oleh pihak lainnya. Reaksi atau perasaan emosional mengakibatkan seseorang berperilaku dengan bias. Meskipun mereka berusaha memaksimalkan utilitas yang diharapkan, mereka mungkin menggunakan informasi yang 'salah'. Selain itu, mereka dapat memperbarui keyakinan mereka dengan menggunakan evaluasi afektif untuk menilai ukuran kesejahteraan emosional (emotional wellbeing) dan evaluasi kognitif mereka terhadap pola konsumsi. Faktor emosi menjadi sebuah hal yang penting karena mereka menentukan perilaku agen secara langsung maupun secara tidak langsung dengan mempengaruhi evaluasi kognitif individu. Dengan memasukkan faktor emosi individu sebagai pertimbangan untuk menilai harga aset mengimplikasikan bahwa sentimen investor dapat menjadi penentu langsung harga aset dan juga risiko.

Berdasarkan penjelasan tersebut, maka peneliti membuat sebuah hipotesis sebagai berikut:

Hipotesis 2: Model asset pricing yang ditambahkan faktor sentimen investor adalah model asset pricing yang lebih baik daripada model asset pricing yang tidak menambahkan faktor sentimen investor.

\section{METODE PENELITIAN}

Desain penelitian ini adalah hypothesis testing dan uji kelayakan model. Populasi penelitian ini adalah perusahaan-perusahaan yang termasuk dalam kesembilan sektor industri yang terdaftar di Bursa Efek Indonesia pada periode 2013-2017. Pengambilan sampel menggunakan metode purposive sampling dan kriteria sampel dipilih berdasarkan kriteria sebagai berikut: (1) tercatat sebagai emiten yang aktif di Bursa Efek Indonesia (BEI) selama tahun 2013-2017 secara berurutan dari bulan Januari 2013 sampai dengan Desember 2017, (2) memiliki data kapitalisasi pasar (market capitalization) di setiap bulan Januari dan Juli, (3) mengeluarkan laporan keuangan secara berkala serta memiliki data book value pada akhir bulan, dan (4) tidak memiliki rasio book-to-market equity negatif selama periode penelitian. Dari proses sampling tersebut diperoleh sebanyak 381 emiten yang layak untuk digunakan sebagai sampel penelitian.

Menurut data-data yang digunakan adalah Indeks Keyakinan Konsumen (IKK) bulanan yang diperoleh dari laman situs Bank Indonesia, indeks bulanan sembilan sektor industri secara bulanan yang diperoleh dari database Bursa Efek Indonesia (BEI) maupun TICMI, data yield obligasi 5 tahun pemerintah Indonesia sebagai proksi risk-free rate yang diperoleh dari situs Indonesia Bond Pricing Agency (IBPA), data bulanan country risk premium yang diperoleh dari database yang 
disediakan oleh New York University, dan data monthly market capitalization dan monthly book value (PBV) diperoleh dari JSX Monthly Statistics.

Penelitian ini berupaya mengetahui pengaruh variabel sentimen investor, market premium, SMB, dan HML terhadap expected return berdasarkan dua bentuk asset pricing models, yaitu conditional three-factor asset pricing model dan unconditional three-factor asset pricing model. Conditional three-factor asset pricing model adalah model three-factor asset pricing model yang menambahkan sentiment investor sebagai indikator tambahan pengukur risiko selain market premium $\left(\mathrm{R}_{\mathrm{m}}-\mathrm{R}_{\mathrm{f}}\right)$, size premium (SMB), dan value premium (HML). Sedangkan unconditional three-factor asset pricing model adalah model dasar three-factor asset pricing model. Penggunaan kedua model pengukuran tersebut mengikuti model yang digunakan oleh Bathia dan Breddin (2018). Kedua model tersebut dianalisis dengan menggunakan metode Robust Least Squared (RLS) untuk analisis data yang bersifat time series dan Generalised Least Squared (GLS) untuk data yang bersifat panel. Secara matematik, model conditional (1) dan unconditional (2) dapat diformulasikan dalam bentuk rumusrumus sebagai berikut:

$$
\begin{aligned}
& R_{i, t}-R_{f}=\alpha+\beta_{1} \operatorname{Sent}_{t-1}+\beta_{2}\left(R_{m}-R_{f}\right)_{t}+\beta_{3} S M B_{i, t}+\beta_{4} H M L_{i, t}+\varepsilon_{i, t} \\
& R_{i, t}-R_{f}=\alpha+\beta_{1}\left(R_{m}-R_{f}\right)_{t}+\beta_{2} S M B_{i, t}+\beta_{3} H M L_{i, t}+\varepsilon_{i, t}
\end{aligned}
$$

Dimana:

$$
\begin{array}{lll}
R_{i, t}-R_{f} & = & \text { expected return saham } i \\
\alpha & = & \text { konstanta } \\
R_{f} & = & \text { risk free rate asset } \\
\text { Sent } & = & \text { lag1 Indeks Keyakinan Konsumen } \\
R_{m} & = & \text { rate of return on market } \\
\text { SMB } & = & \text { selisih value weighted return portofolio saham kecil dan value weighted return } \\
& \text { portofolio saham kapitalisasi besar. } \\
\text { HML } & \text { selisih value weighted return portofolio saham dengan book-to-market tinggi dan } \\
& \text { value weighted return portofolio saham book-to-market rendah. } \\
\beta_{1}, \beta_{2}, \beta_{3}, \beta_{4}= & \text { slope regresi }
\end{array}
$$

\section{HASIL DAN PEMBAHASAN}

Dari sampel yang dipilih, dibentuk portofolio bulanan dengan metode two sequential sort berdasarkan book-to-market dan kapitalisasi pasar sehingga diperoleh 9 portofolio setiap enam bulan sekali yang dimulai dari bulan Januari 2013 hingga Desember 2017. Proses pembentukan portofolio tersebut membuat sampel emiten dari setiap sektor industri dari setiap portofolio berbeda pada enam bulan pertama dengan enam bulan berikutnya setiap tahunnya dan hasil ini mengindikasikan nilai perusahaan selalu berfluktuatif dan dinilai beragam oleh para investor saham yang ada di pasar modal Indonesia. Menurut Fama (1996) menyatakan bahwa perhitungan return dapat menggunakan metode value-weighted sehingga return variance dapat diminimalisasi dalam data observasi. Penggunaan 
metode value-weighted juga dapat menggambarkan perilaku return berdasarkan klasifikasi saham dengan lebih baik (Fama, 1993).

\section{Analisis Deskriptif}

Ringkasan statistik ini memberikan informasi secara agregat data yang digunakan untuk melakukan pengujian hipotesis. Ringkasan statistik penelitian ini ditampilkan pada Tabel 1. berikut:

Tabel 1. Statistik Deskriptif

\begin{tabular}{|c|c|c|c|c|c|c|}
\hline Variabel & $\mathrm{N}$ & Mean & Median & Maximum & Minimum & $\begin{array}{c}\text { Standard } \\
\text { Deviation }\end{array}$ \\
\hline $\mathrm{R}_{\text {agriculture }}$ & 60 & $-0,0018$ & 0,0023 & 0,1556 & $-0,1715$ & 0,0673 \\
\hline $\mathrm{R}_{\text {mining }}$ & 60 & $-0,0007$ & $-0,0008$ & 0,1366 & $-0,1265$ & 0,0623 \\
\hline $\mathrm{R}_{\text {basic }}$ & 60 & 0,0062 & 0,0104 & 0,1252 & $-0,1226$ & 0,0580 \\
\hline $\mathrm{R}_{\mathrm{misc}}$ & 60 & 0,0021 & $-0,0003$ & 0,1014 & $-0,1685$ & 0,0554 \\
\hline $\mathrm{R}_{\text {consumer }}$ & 60 & 0,0109 & 0,0123 & 0,1333 & $-0,0766$ & 0,0407 \\
\hline $\mathrm{R}_{\text {property }}$ & 60 & 0,0092 & 0,0087 & 0,1708 & $-0,1627$ & 0,0671 \\
\hline $\mathrm{R}_{\text {infrastructure }}$ & 60 & 0,0052 & 0,0117 & 0,0653 & $-0,093$ & 0,0396 \\
\hline $\mathrm{R}_{\text {finance }}$ & 60 & 0,0136 & 0,0169 & 0,1129 & $-0,1526$ & 0,0519 \\
\hline $\mathrm{R}_{\text {trade }}$ & 60 & 0,0044 & 0,0057 & 0,0993 & $-0,0943$ & 0,0384 \\
\hline $\mathrm{R}_{\mathrm{m}}-\mathrm{R}_{\mathrm{f}}$ & 60 & 0,0066 & 0,0115 & 0,0768 & $-0,0901$ & 0,0347 \\
\hline Sent $_{t}$ & 60 & 115,139 & 116,189 & 126,357 & 97,482 & 5,9671 \\
\hline $\mathrm{SMB}_{\text {agriculture }}$ & 60 & 0,0092 & 0,0167 & 0,4536 & $-0,3185$ & 0,1437 \\
\hline $\mathrm{SMB}_{\text {mining }}$ & 60 & 0,0158 & 0,0164 & 0,4263 & $-0,5775$ & 0,1730 \\
\hline $\mathrm{SMB}_{\text {basic }}$ & 60 & 0,0259 & 0,0446 & 1,0203 & $-0,6540$ & 0,2933 \\
\hline $\mathrm{SMB}_{\mathrm{misc}}$ & 60 & 0,0765 & 0,0233 & 0,9377 & $-0,4690$ & 0,2843 \\
\hline $\mathrm{SMB}_{\text {consumer }}$ & 60 & 0,0067 & $-0,0207$ & 0,7055 & $-0,3539$ & 0,2263 \\
\hline $\mathrm{SMB}_{\text {property }}$ & 60 & 0,0223 & $-0,0454$ & 2,1274 & $-0,5834$ & 0,4670 \\
\hline $\mathrm{SMB}_{\text {infrastructure }}$ & 60 & $-0,0092$ & $-0,0420$ & 0,6112 & $-0,5374$ & 0,2535 \\
\hline $\mathrm{SMB}_{\text {finance }}$ & 60 & 0,0123 & 0,0411 & 0,9477 & $-0,9514$ & 0,3980 \\
\hline $\mathrm{SMB}_{\text {trade }}$ & 60 & 0,1099 & 0,1299 & 1,4282 & $-0,7117$ & 0,3832 \\
\hline HML agriculture & 60 & $-0,0085$ & $-0,0282$ & 0,4269 & $-0,2791$ & 0,1662 \\
\hline HML mining & 60 & 0,0332 & 0,0236 & 0,7585 & $-0,6164$ & 0,2308 \\
\hline HML basic $_{\text {b }}$ & 60 & $-0,0089$ & $-0,0132$ & 0,6941 & $-0,6162$ & 0,2657 \\
\hline $\mathrm{HML}_{\text {misc }}$ & 60 & 0,0792 & 0,0784 & 0,9992 & $-0,5789$ & 0,3250 \\
\hline $\mathrm{HML}_{\text {consumer }}$ & 60 & $-0,0122$ & $-0,0412$ & 0,8982 & $-0,7494$ & 0,2895 \\
\hline HML property & 60 & $-0,0801$ & $-0,1167$ & 1,0313 & $-0,9036$ & 0,2082 \\
\hline HML infrastructure & 60 & $-0,0007$ & $-0,0125$ & 0,8623 & $-0,7487$ & 0,3028 \\
\hline $\mathrm{HML}_{\text {finance }}$ & 60 & 0,0460 & 0,0270 & 1,0461 & $-0,6848$ & 0,3635 \\
\hline $\mathrm{HML}_{\text {trade }}$ & 60 & 0,0685 & 0,0948 & 1,1718 & $-0,9075$ & 0,4633 \\
\hline
\end{tabular}

Sumber: Data diolah, 2019

Dari hasil Tabel 1. terdapat 60 total data observasi yang valid untuk masing-masing variabel. Dari sembilan variabel return industri yang menjadi variabel dependen terdapat hanya dua variabel yang menunjukkan nilai rata-rata (mean) bernilai negatif yaitu $\mathrm{R}_{\text {agriculture }}$ dan $\mathrm{R}_{\operatorname{mining}}$ dimana masingmasing nilai rata-rata dari kedua variabel dependen tersebut bernilai $-0,0018(-0,18 \%)$ dan $-0,0007$ (0,07\%). Hasil tersebut menunjukkan tren kinerja investasi yang menurun pada sektor agrikultur 
sebesar $0,18 \%$ dan sektor pertambangan sebesar $0,07 \%$. Hasil yang berbeda ditunjukkan pada nilai koefisien rata-rata Risk Premium $\left(\mathrm{R}_{\mathrm{m}}-\mathrm{R}_{\mathrm{f}}\right)$ dimana nilai koefisien pada variabel ini memiliki besaran nilai koefisien yang positif sebesar 0,0066 (0,66\%). Nilai koefisien tersebut mengindikasikan kinerja tingkat pengembalian pasar modal memiliki kinerja yang lebih baik sebesar 0,66\% dibandingkan dengan kinerja tingkat pengembalian yang dimiliki instrumen aset bebas risiko (obligasi pemerintah 5 tahun) selama periode Januari 2013 hingga Desember 2017.

Pada variabel Sentimen Investor (Sent $\mathrm{t}_{\mathrm{t}}$ ) secara rata-rata mencerminkan tingkat keyakinan investor yang cukup tinggi dimana hal ini tercermin pada nilai koefisien dari variabel sentimen investor y ang diproksikan dengan Indeks Keyakinan Konsumen (IKK) memiliki nilai sebesar 115,138. Kesimpulan mengenai sentimen investor tersebut mengacu pada penjelasan survei konsumen oleh Bank Indonesia pada tanggal 22 Maret 2013 yang menjelaskan apabila Indeks Keyakinan Konsumen (IKK) berada diatas 100 berarti optimis dan sebaliknya apabila dibawah 100 berarti pesimis.

Pada variabel Small Minus Big (SMB) terdapat delapan sektor industri yang memiliki koefisien bernilai positif dan satu sektor industri yang memiliki nilai koefisien yang bernilai negatif. Hasil tersebut disimpulkan bahwa secara rata-rata kinerja tingkat pengembalian investasi yang lebih baik adalah perusahaan-perusahaan berukuran kecil yang bergerak di sektor agrikultur, sektor tambang, sektor industri dasar dan kimia, sektor aneka industri, sektor barang konsumsi, sektor properti, real estate, dan konstruksi, sektor keuangan dan sektor perdagangan, jasa, dan investasi daripada kinerja tingkat pengembalian investasi pada perusahaan-perusahaan kecil yang ada di sektor infrastruktur. Secara garis besar dari paparan data tersebut mengindikasikan keberadaan small firm effect (size effect) pada sektor agrikultur, tambang, dasar dan kimia, macam-macam, barang konsumsi, properti, real estate, dan konstruksi, keuangan dan perdagangan namun tidak pada sektor infrastruktur.

Pada variabel High Minus Low (HML) terdapat empat sektor industri yang memiliki nilai koefisien positif dan lima sektor industri yang memiliki nilai koefisien negatif. Keempat sektor industri tersebut adalah sektor pertambangan, sektor aneka industri, sektor keuangan, dan sektor perdagangan, jasa, dan investasi. Hasil tersebut menjelaskan bahwa kinerja tingkat pengembalian investasi dari perusahaan-perusahaan growth lebih baik daripada perusahaan-perusahaan value yang ada di sektor industri pertambangan, macam-macam, keuangan, dan perdagangan. Namun, hasil yang berbeda dapat dilihat pada sektor industri agrikultur, dasar dan kimia, barang konsumsi, properti, real estate, dan konstruksi, dan infrastruktur dimana kelima sektor industri ini memiliki nilai rata-rata koefisien yang negatif. Hasil tersebut menjelaskan bahwa kinerja tingkat pengembalian investasi dari perusahaan- perusahaan value lebih baik daripada perusahaan-perusahaan growth yang ada di sektor agrikultur, sektor industri dasar dan kimia, sektor barang konsumsi, sektor properti, real estate, dan konstruksi, dan sektor infrastruktur, utilitas, dan transportasi. Secara garis besar dari hasil tersebut mengindikasikan value premium effect dapat ditemukan pada sektor industri agrikultur, sektor dasar 
dan kimia, sektor barang konsumsi, sektor properti, real estate, dan sektor konstruksi dan sektor infrastruktur, utilitas, dan transportasi namun tidak pada sektor pertambangan, macam-macam, keuangan, dan perdagangan.

\section{Pengujian Hipotesis}

Tujuan utama dari analisis model regresi adalah untuk membandingkan koefisien regresi dan koefisien adjusted $R^{2}$ yang dihasilkan masing-masing dari model regresi conditional three-factor asset pricing model dan unconditional three-factor asset pricing model. Koefisien-koefisien regresi yang dihasilkan dari kedua model regresi tersebut menjadi indikator untuk melihat variabel-variabel independen (sent $\mathrm{t}_{\mathrm{t}-1}, \mathrm{r}_{\mathrm{m}}-\mathrm{r}_{\mathrm{f}}$, smb, dan $\mathrm{hml}$ ) mana yang berkaitan dengan variabel dependen (return industri) terutama pengaruh sentimen investor terhadap return industri. Adjusted $R^{2}$ juga digunakan untuk membandingkan kinerja diantara kedua model tersebut. Hasil dari semua proses regresi tersebut dapat dilihat pada Tabel 2. untuk model conditional dan Tabel 3. untuk model unconditional.

Tabel 2. Output Regresi Conditional Three-Factor Asset Pricing Model

\begin{tabular}{|c|c|c|c|c|c|c|}
\hline \multirow[b]{2}{*}{ Industri } & \multicolumn{6}{|c|}{ Koefisien Regresi } \\
\hline & $\alpha$ & $\begin{array}{l}\text { Sent } t_{t-1} \\
\left(\beta_{1}\right)\end{array}$ & $\begin{array}{c}\mathrm{R}_{\mathrm{m}}-\mathrm{R}_{\mathrm{f}} \\
\left(\beta_{2}\right)\end{array}$ & $\begin{array}{c}\mathrm{SMB} \\
\left(\beta_{3}\right)\end{array}$ & $\begin{array}{c}\mathrm{HML} \\
\left(\beta_{4}\right)\end{array}$ & $\begin{array}{c}\text { Adj. } R^{2} \\
(\%)\end{array}$ \\
\hline Agrikultur & $\begin{array}{c}-0,0169 \\
(0,0522)\end{array}$ & $\begin{array}{c}0,0001 \\
(0,0005)\end{array}$ & $\begin{array}{c}0,6967 * * * \\
(0,2113)\end{array}$ & $\begin{array}{c}-0,2912^{* * *} \\
(0,0840)\end{array}$ & $\begin{array}{c}0,0158 \\
(0,0724)\end{array}$ & 31,64 \\
\hline Pertambangan & $\begin{array}{c}0,0077 \\
(0,0522)\end{array}$ & $\begin{array}{c}-0,0001 \\
(0,0005)\end{array}$ & $\begin{array}{c}0,5609 * * * \\
(0,2088)\end{array}$ & $\begin{array}{c}-0,2612^{* * *} \\
(0,0595)\end{array}$ & $\begin{array}{c}0,0884 * * \\
(0,0442)\end{array}$ & 18,84 \\
\hline $\begin{array}{l}\text { Dasar dan } \\
\text { Kimia }\end{array}$ & $\begin{array}{c}0,0071 \\
(0,0331)\end{array}$ & $\begin{array}{l}-0,0001 \\
(0,0003)\end{array}$ & $\begin{array}{c}1,1707^{* * *} \\
(0,1370)\end{array}$ & $\begin{array}{c}0,0181 \\
(0,0255)\end{array}$ & $\begin{array}{c}-0,0685^{* *} \\
(0,0291)\end{array}$ & 55,33 \\
\hline Aneka Industri & $\begin{array}{c}-0,0075 \\
(0,0356)\end{array}$ & $\begin{array}{c}0,0001 \\
(0,0003)\end{array}$ & $\begin{array}{c}1,3653 * * * \\
(0,1611)\end{array}$ & $\begin{array}{c}-0,0321 \\
(0,0262)\end{array}$ & $\begin{array}{c}-0,0104 \\
(0,0236)\end{array}$ & 46,16 \\
\hline $\begin{array}{l}\text { Barang } \\
\text { konsumsi }\end{array}$ & $\begin{array}{c}0,0073 \\
(0,0282)\end{array}$ & $\begin{array}{c}0,0000 \\
(0,0002)\end{array}$ & $\begin{array}{c}0,7127 * * * \\
(0,1144)\end{array}$ & $\begin{array}{c}0,0036 \\
(0,0320)\end{array}$ & $\begin{array}{c}-0,0271 \\
(0,0245)\end{array}$ & 33,47 \\
\hline $\begin{array}{l}\text { Properti, real } \\
\text { estate, dan } \\
\text { konstruksi } \\
\text { bangunan }\end{array}$ & $\begin{array}{c}0,0712^{* *} \\
(0,0356)\end{array}$ & $\begin{array}{c}-0,0007^{* *} \\
(0,0003)\end{array}$ & $\begin{array}{c}1,3642 * * * \\
(0,1420)\end{array}$ & $\begin{array}{c}-0,0509 * * * \\
(0,0131)\end{array}$ & $\begin{array}{c}-0,0098 \\
(0,0150)\end{array}$ & 53,21 \\
\hline $\begin{array}{l}\text { Infrastruktur, } \\
\text { utilitas, dan } \\
\text { transportasi }\end{array}$ & $\begin{array}{c}0,0318 \\
(0,0292)\end{array}$ & $\begin{array}{c}-0,0003 \\
(0,0003)\end{array}$ & $\begin{array}{c}0,7999 * * * \\
(0,1190)\end{array}$ & $\begin{array}{c}-0,0401 \\
(0,0258)\end{array}$ & $\begin{array}{c}0,0215 \\
(0,0215)\end{array}$ & 34,64 \\
\hline Keuangan & $\begin{array}{c}0.0508^{* *} \\
(0,0213)\end{array}$ & $\begin{array}{c}-0,0004^{* *} \\
(0,0002)\end{array}$ & $\begin{array}{c}1.2166 * * * \\
(0,0957)\end{array}$ & $\begin{array}{c}-0,0054 \\
(0,0103)\end{array}$ & $\begin{array}{c}-0,0237 * * * \\
(0,0110)\end{array}$ & 61,24 \\
\hline $\begin{array}{l}\text { Perdagangan, } \\
\text { jasa, dan } \\
\text { investasi }\end{array}$ & $\begin{array}{c}-0,0095 \\
(0,0248)\end{array}$ & $\begin{array}{c}0,0001 \\
(0,0002)\end{array}$ & $\begin{array}{c}0,6805^{* * *} \\
(0,1098)\end{array}$ & $\begin{array}{c}-0,0299 * * * \\
(0,0105)\end{array}$ & $\begin{array}{c}0,0056 \\
(0,0086)\end{array}$ & 45,67 \\
\hline
\end{tabular}

Sumber: Data diolah, 2019

Keterangan: (..) : standard error, ***: signifikan pada confidence interval 1\%, **: singnifikan pada confidence interval 5\%, * : signifikan pada confidence interval $10 \%$.

Berdasarkan Tabel 2. di atas memberikan beberapa informasi yang menarik dimana nilai konstan yang signifikan hanya ditemukan pada sektor properti, real estate, dan konstruksi bangunan dan sektor industri keuangan. Hasil tersebut dapat didefinisikan bahwa apabila variabel-variabel 
market premium $\left(\mathrm{R}_{\mathrm{m}}-\mathrm{R}_{\mathrm{f}}\right)$, size premium (SMB), dan value premium (HML) bernilai konstan, maka sektor keuangan akan terus menunjukkan tren yang positif di negara Indonesia dibandingkan dengan delapan sektor industri lainnya.

Selain itu, peneliti juga menemukan bahwa semua sektor industri yang ada di Indonesia dipengaruhi oleh variabel market premium $\left(\mathrm{R}_{\mathrm{m}}-\mathrm{R}_{\mathrm{f}}\right)$ dan temuan ini mengindikasikan mayoritas perusahaan-perusahaan yang beroperasi di industrinya dipengaruhi oleh kondisi dan situasi pasar Indonesia. Untuk variabel size premium (SMB) hanya sektor agrikultur, pertambangan, properti, real estate, dan konstruksi bangunan, dan perdagangan, jasa, dan investasi saja yang sensitif dan signifikan terhadap return industri dengan nilai koefisien yang negatif. Hasil tersebut mengindikasikan bahwa size effect dapat ditemukan pada perusahaan-perusahaan yang tergolong pada keempat industri tersebut namun size effect tersebut lebih terlihat pada perusahaan-perusahaan yang memiliki kapitalisasi pasar besar. Untuk variabel value-premium (HML) hanya sektor pertambangan, sektor dasar dan kimia, dan sektor keuangan yang sensitif dan signifikan terhadap return industri namun ketiga sektor industri tersebut memiliki nilai koefisien yang berbeda dimana sektor pertambangan memiliki nilai koefisien yang positif dan sektor dasar dan kimia dan sektor keuangan yang memiliki nilai negatif. Secara garis besar value premium hanya ditemukan pada sektor industri pertambangan dan growth premium hanya ditemukan pada sektor industri dasar dan kimia serta sektor keuangan. Selanjutnya, variabel sentimen investor yang diproksikan dengan Indeks Keyakinan Konsumen (IKK). Variabel sentimen investor ternyata memberikan pengaruh negatif dan signifikan pada sektor industri properti, real estate, dan konstruksi bangunan dan sektor keuangan saja. Hasil ini mendukung hipotesis pertama yang mengatakan sentimen investor berpengaruh negatif terhadap return industri.

Cara pengujian hipotesis kedua adalah dengan membandingkan kinerja conditional threefactor asset pricing model dengan kinerja unconditional three-factor asset pricing model dan proses perbandingan tersebut mengacu pada nilai koefisien adjusted $R^{2}$ dari masing model regresi pada setiap sektor industri. Sebuah model regresi yang baik memiliki nilai koefisien adjusted $R^{2}$ yang lebih besar (Bathia and Bredin, 2018). Hasil tersebut dapat dilihat pada Tabel 3.

Dari Tabel 3. diperoleh bahwa kinerja conditional three-factor asset pricing model hanya ditemukan pada model regresi untuk mengukur sektor industri properti, real estate, dan konstruksi bangunan dan sektor industri keuangan dimana masing-masing koefisien adjusted $R^{2}$ pada kedua model tersebut meningkat sebesar 0,89\% dan 9,38\%. Namun, nilai koefisien adjusted $R^{2}$ yang berbeda ditemukan pada model regresi untuk sektor agrikultur, pertambangan, dasar dan kimia, aneka industri, barang konsumsi, infrastruktur, utilitas, dan transportasi, serta perdagangan, jasa, dan investasi dimana kinerja model tersebut menurun sebesar $-1,29 \%,-1,40 \%,-0,03 \%,-1,42 \%,-1,21 \%,-0,06 \%$, dan $-0,48 \%$ secara berturut-turut. Dapat disimpulkan bahwa hipotesis kedua terdukung dimana model asset pricing yang ditambahkan faktor sentimen investor adalah model asset pricing yang lebih baik daripada model asset pricing yang tidak menambahkan faktor sentimen investor sebagian terdukung 
Tabel 3. Output Regresi Unconditional Three-Factor Asset Pricing Model

\begin{tabular}{lccccc}
\hline \multirow{2}{*}{ Industri } & \multicolumn{5}{c}{ Koefisien Regresi } \\
\cline { 2 - 6 } & $\alpha$ & $\mathrm{R}_{\mathrm{m}}-\mathrm{R}_{\mathrm{f}}$ & $\mathrm{SMB}$ & $\mathrm{HML}$ & Adj. $\mathrm{R}^{2}(\%)$ \\
\hline \multirow{2}{*}{ Agrikultur } & $-0,0051$ & $0,6983^{* * *}$ & $-0,2924^{* * *}$ & 0,0171 & 32,93 \\
& $(0,0073)$ & $(0,2087)$ & $(0,0830)$ & $(0,0713)$ & \\
Pertambangan & $-0,0057$ & $0,5587^{* * *}$ & $-0,2658^{* * *}$ & $0,0915^{* *}$ & 20,24 \\
& $(0,0072)$ & $(0,2070)$ & $(0,0581)$ & $(0,0431)$ & \\
Dasar dan Kimia & $-0,0029$ & $1,1632^{* * *}$ & 0,0187 & $-0,0703^{* *}$ & 55,36 \\
& $(0,0046)$ & $(0,1352)$ & $(0,0252)$ & $(0,0284)$ & \\
Aneka Industri & $-0,0016$ & $1,3617^{* * *}$ & $-0,0326$ & $-0,0094$ & 47,58 \\
Barang konsumsi & $(0,0050)$ & $(0,1585)$ & $(0,0257)$ & $(0,0232)$ & \\
& 0,0038 & $0,7109^{* * *}$ & 0,0023 & $-0,0260$ & 34,68 \\
Properti, real estate, & $(0,0038)$ & $(0,1124)$ & $(0,0305)$ & $(0,0234)$ & \\
dan konstruksi & $-0,0039$ & $1,3501^{* * *}$ & $-0,0578^{* * *}$ & $-0,0058$ & 52,32 \\
bangunan & $(0,0052)$ & $(0,1446)$ & $(0,0132)$ & $(0,0153)$ & \\
Infrastruktur, utilitas, & 0,0017 & $0,7923^{* * *}$ & $-0,0415$ & 0,0220 & \\
dan transportasi & $(0,0041)$ & $(0,1192)$ & $(0,0259)$ & $(0,0215)$ & 34,70 \\
Keuangan & $0,0068^{* *}$ & $1,2126^{* * *}$ & $-0,0054$ & $-0,0240 * *$ & \multirow{2}{*}{51,86} \\
Perdagangan, jasa, dan & $(0,0030)$ & $(0,0955)$ & $(0,0104)$ & $(0,0109)$ & \\
investasi & 0,0024 & $0,6811^{* * *}$ & $-0,0300^{* * *}$ & 0,0057 & 46,15 \\
\hline
\end{tabular}

Sumber: Data diolah, 2019

Keterangan: (..) : standard error, ***: signifikan pada confidence interval 1\%, **: singnifikan pada confidence interval 5\%, * : signifikan pada confidence interval $10 \%$.

karena hipotesis kedua hanya terbukti di sektor properti, real estate, dan konstruksi bangunan dan sektor keuangan.

Untuk memperkuat hasil pengujian pada penelitian ini, maka pengujian terhadap kedua hipotesis pada penelitian ini selanjutnya menggunakan regresi Generalised Least Squared (GLS) pada keseluruhan industri dan analisis dari perspektif data panel. Hasil analisis tersebut dapat dilihat pada Tabel 4. dan Tabel 5.

Secara garis besar, hasil yang tertera pada Tabel 4. dan Tabel 5. diatas mendukung kedua hipotesis yang telah diajukan dalam penelitian ini dimana sentimen investor tetap berpengaruh negatif terhadap return industri dan meningkatkan kinerja three-factor asset pricing model sebesar 0,23\%.

Tabel 4. Output Regresi GLS Conditional Three-Factor Asset Pricing Model

\begin{tabular}{ccccccc}
\hline \multirow{2}{*}{ Industri } & \multicolumn{7}{c}{ Koefisien Regresi } \\
\cline { 2 - 7 } & $\alpha$ & $\begin{array}{c}\text { Sent } \mathrm{t}_{\mathrm{-}-1} \\
\left(\beta_{1}\right)\end{array}$ & $\begin{array}{c}\mathrm{R}_{\mathrm{m}}-\mathrm{R}_{\mathrm{f}} \\
\left(\beta_{2}\right)\end{array}$ & $\begin{array}{c}\text { SMB } \\
\left(\beta_{3}\right)\end{array}$ & $\begin{array}{c}\text { HML } \\
\left(\left(\beta_{4}\right)\right.\end{array}$ & $\begin{array}{c}\text { Adj. } \mathrm{R}^{2} \\
(\%)\end{array}$ \\
\hline \multirow{3}{*}{ Agregat } & $0,0230^{*}$ & $-0,0002^{*}$ & $0,9320^{* * *}$ & $-0,0189 * *$ & $-0,0198^{* * *}$ & 39,54 \\
& $(0,0131)$ & $(0,0001)$ & $(0,0530)$ & $(0,0076)$ & $(0,0072)$ & \\
\hline
\end{tabular}

Sumber: Data diolah, 2019

Keterangan: (..) : standard error, ***: signifikan pada confidence interval 1\%, **: singnifikan pada confidence interval 5\%, * : signifikan pada confidence interval $10 \%$. 
Tabel 5. Output Regresi GLS Unconditional Three-Factor Asset Pricing Model

\begin{tabular}{cccccc}
\hline \multirow{2}{*}{ Industri } & \multicolumn{5}{c}{ Koefisien Regresi } \\
\cline { 2 - 6 } & $\alpha$ & $\mathrm{R}_{\mathrm{m}-\mathrm{R}_{\mathrm{f}}}$ & SMB & HML & $\begin{array}{c}\text { Adj. } \mathrm{R}^{2} \\
(\%)\end{array}$ \\
\hline \multirow{2}{*}{ Agregat } & 0,0002 & $0,9272^{* * *}$ & $-0,0194^{* *}$ & $-0,0199^{* * *}$ & 39,31 \\
\hline
\end{tabular}

Sumber: Data diolah, 2019

Keterangan: (..) : standard error, ***: signifikan pada confidence interval 1\%, **: singnifikan pada confidence interval 5\%, * : signifikan pada confidence interval $10 \%$.

\section{Pembahasan}

Hingga saat ini ada tiga bahasan utama yang menjadi alasan penelitian yang mengangkat topik sentimen investor diberbagai penelitian yaitu: (1) apakah sentimen investor yang tinggi (optimis) memiliki pola hubungan yang negatif terhadap return investasi di masa yang akan datang, (2) jenis aset manakah yang sensitif terhadap sentimen investor jika diteliti dari segi tingkat pengembalian investasi di masa depan (future returns), dan (3) jenis aset seperti apakah yang sensitif terhadap sentimen investor jika diteliti dari segi pergerakan harga aset tersebut dipasar keuangan (price changes).

Untuk pengujian hipotesis pertama, hasil analisis membuktikan bahwa sentimen investor memiliki pengaruh yang negatif terhadap return industri, khususnya sektor industri properti, real estate, dan konstruksi bangunan dan sektor keuangan. Temuan ini sejalan dengan beberapa penelitian terdahulu yang memberikan hasil yang serupa dengan hasil analisis regresi yang dilakukan oleh Brown and Cliff (2004); Chen (2009); Lemmon and Portniaguina (2006); Stambaugh et al. (2012); Xu and Green (2012), Huang et al. (2014); Apergis and Rehman (2018); Lao et al. (2018) dan Lam and Hui (2018). Pengaruh negatif yang diberikan oleh variabel sentimen investor memberikan penjelasan bahwa fenomena mispricing dapat ditemukan pada pasar modal Indonesia terutama pada sektor properti, real estate, dan konstruksi bangunan dan sektor keuangan.

Fenomena mispricing tersebut terjadi karena adanya limits to arbitrage dan hard-to-value assets. Untuk memahami mengapa kedua fenomena tersebut terjadi kita harus memahami bahwa ada tiga pihak yang terlibat didalam transaksi pasar yaitu noise traders, arbitrageurs, dan para investor yang memiliki dana arbitrase yang tidak melakukan aktivitas perdagangan secara langsung (Schleifer and Vishny, 1997). Proses penilaian harga aset yang terjadi di pasar keuangan biasanya lebih b anyak disebabkan oleh pihak noise traders dan arbitrageurs. Arbitrageurs memainkan peran penting dalam analisis pasar sekuritas karena peranan utamanya adalah untuk membawa harga aset ke nilai -nilai fundamental dan menjaga pasar tetap efisien (Shleifer and Vishny, 1997) dan apabila peranan arbitrageurs tidak kuat maka nilai aset yang ditransaksikan tidak akan pernah dilakukan pada nilai fundamental. Transaksi-transaksi seperti ini lebih mudah dijumpai pada aset-aset yang sulit dinilai (hard-to-value) dimana nilai-nilai aset tersebut memiliki subjektivitas yang tinggi pada proses penilaiannya (Lam and Hui, 2018). 
Pengaruh sentimen investor yang negatif terhadap return industri dapat dijelaskan dari teori liquidity preference theory. Teori ini pada dasarnya menjelaskan bahwa seorang investor mensyaratkan tingkat premi yang lebih tinggi pada sekuritas-sekuritas jangka menengah dan jangka panjang daripada sekuritas-sekuritas jangka pendek karena aset-aset jangka menengah dan panjang tersebut memiliki risiko yang lebih besar dan membuat investor menyukai kas atau sekuritas yang likuid lainnya dimana aset-aset ini lebih mudah ditemui pada industri keuangan. Industri keuangan merupakan industri yang secara langsung memperdagangkan instrumen keuangan sebagai komodit as utamanya dan tentu saja sangat disukai oleh investor karena sifat dasar dari uang itu sendiri adalah likuid dan mudah untuk dijual penuh secara langsung dan memberikan peluang bagi para investor untuk melakukan transaksi dengan motif spekulasi. Motif spekulasi juga menjadi satu dari antara tiga motif seorang investor menginginkan aset yang memiliki likuiditas yang tinggi (Keynes, 1936).

Namun, penjelasan pengaruh negatif sentimen investor yang ditemukan pada sektor properti, real estate, dan konstruksi bangunan tidak dapat sepenuhnya menggunakan teori liquidity preference theory karena komoditas yang diperdagangkan memiliki sifat yang illikuid dan rentan terhadap asimetri informasi (Giacomini, 2017; Lam and Hui, 2018; Lao et al., 2018). Salah satu alasan kuat yang dapat menjelaskan hal tersebut karena transaksi komoditas yang diperdagangkan didalam industri ini lebih didominasi oleh aktivitas noise trader (Barkham and Ward, 1999) dan dijual tidak secara berkala dalam rentang waktu hitungan tahun bahkan beberapa dekade (Shiller, 2015). Keberadaan noise trader ini kembali memberikan konfirmasi keberadaan transaksi perdagangan yang irrasional dalam melakukan penilaian komoditas dan terjadinya fenomena irrational exuberance dari para investor.

Peranan sentimen investor tidak bisa diabaikan di dalam melakukan penilaian harga aset karena hasil empirik yang telah dipaparkan pada penelitian ini membuktikan adanya peningkatan kinerja asset pricing yang menambahkan faktor sentimen investor terutama pada sektor properti, real estate, dan konstruksi bangunan dan sektor keuangan sebesar 0,89\% dan 9,38\% secara berturut-turut. Hasil tersebut sejalan dengan hasil penelitian yang telah dilakukan oleh Dash dan Mahakud (2013); Chau et al. (2016), serta Bathia and Bredin (2018).

\section{KESIMPULAN}

Penelitian ini telah membuktikan bahwa sentimen investor memiliki pengaruh terhadap sektor industri yang ada di Indonesia terutama pada sektor properti, real estate, dan konstruksi bangunan dan sektor keuangan. Penjelasan empirik yang dapat digunakan untuk menjelaskan sentimen investor memiliki pengaruh pada kedua sektor ini karena sektor properti, real estate, dan konstruksi bangunan merupakan sektor industri yang memperdagangkan komoditas yang proses penilaiannya lebih dipengaruhi oleh faktor subjektivitas sehingga sangat sulit untuk memperoleh nilai fundamental sesungguhnya pada komoditas seperti ini. Sektor keuangan merupakan industri yang memperdagangkan komoditas yang memiliki likuditas yang tinggi dan hal ini sejalan dengan teori 
liquidity preference theory. Secara garis besar, penelitian ini membuktikan bahwa penilaian harga aset dengan menggunakan faktor subjektivitas dapat ditemukan pada pasar modal Indonesia serta optimisme berlebihan yang dimiliki para investor justru menurunkan kinerja investasi portofolio yang mereka miliki. Selain kedua hal tersebut, penelitian ini juga mengindikasikan adanya mispricing dalam valuasi investasi oleh investor yang bertransaksi di pasar modal Indonesia baik secara industri maupun agregat. Sentimen investor juga dapat meningkatkan kinerja model three-factor asset pricing model.

\section{REFERENSI}

Apergis, N., and Rehman, M.U. 2018. Is CAPM a Behavioral Model? Estimating Sentiments from Rationalism. Journal of Behavioral Finance. Vol. 7560 No. 1. Pp: 1-8.

Ball, R. 1978. Anomalies in Relationship Between Securities' Yields Yield-Surrogates. Journal of Financial Economics. Vol. 6. Pp: 103-126.

Bank Indonesia. 2016. Metadata [online]. Avaible at:http://www.bi.go.id [Accesed 4 November 2019].

Banz, R. 1981. The Relationship Between Returns and Market Value of Common Stocks. Journal of Financial Economics. Vol. 6. Pp: 3-18.

Barkham, R.J., and Ward, C.W.R. 1999. Investor Sentiment and Noise Traders: Discount to Net Asset Value in Listed Property Companies in the U.K. Journal of Real Estate Research, American Real Estate Society. Vol. 18 No. 2. Pp: 291-312.

Basu, S. 1977. Investment Performance of Common Stocks in Relation to Their Price of Earnings Ratios: A Test of The Efficient Market Hypothesis. Journal of Finance. Vol. 32. Pp: 663-682.

Bathia, D., and Brendin, D. 2018. Investor Sentiment: Does it Augment the Performance of Asset Pricing. International Review of Financial Analysis. In Proof Reading and Manuscript Corrected.

Bernard, V. L., and Thomas, J. K. 1989. Post-Earnings-Announcement Drift: Delayed Price Response or Risk Premium?. Journal of Accounting Research. Vol. 27. Pp: 1-36.

Bhandari, L. 1988. Debt-Equity Ratio and Expected Common Stock Returns: Empirical Evidence. Journal of Finance, Vol. 19. Pp: 507-528.

Black, F. 1986. Noise Trader. The Journal of Finance. Vol. 41 No. 3. Pp: 529-543.

Brown, G., and M. Cliff. 2004. Investor Sentiment and The Near-Term Stock Market. Journal of Empirical Finance. Vol.11. Pp: 1-27.

Campbell, John Y., and Albert S. Kyle. 1993. Smart Money, Noise Trading and Stock Price Behaviour. The Review of Economic Studies. Vol. 60 No. 1. Pp: 1-34.

Chan, K., and Chen, N. 1988. An Unconditional Asset Pricing Test and The Role of Firm Size as an Instrument Variable for Risk. Journal of Finance. Vol. 43. Pp: 309-325.

Chau, F, Deesomsak, R, and Kuotmos, D. 2016. Does investor sentiment matter?. International Review of Financial Analysis. Vol 48. Pp: 221-232.

Dash, S.R., and Mahakud, J. 2013. Investor Sentiment and Stock Return: Do Industries Matter?. Journal of Applied Economic Research. Vol 7. Pp: 315-349.

D’Avolio, Gene. 2002. The Market for Borrowing Stock. SSRN 66. Pp: 271-306.

De Bondt, Werner, F. M., and Thaler, R.H. 1985. Does the Stock Market Overreact. Journal of Finance. Vol. 40 No. 3. Pp: 793-805.

De Long, Bradford, J, Shleifer, A, Summers, L.H., and Waldmann, R.J. 1990. Noise Trader Risk in Financial Markets. Journal of Political Economy. Vol. 98 No. 4. Pp: 703-738.

Einhorn, H.J., and Hogarth, R.M. 1986. Decision Making Under Ambiguity. The Journal of Business. Vol. 59 No. 4. Pp: 225.

Fama, E.F. and French, K. 1992. The Cross-Section of Expected Returns. Journal of Finance. Vol. 47.

Pp: 427-465. 
Fama, E.F. dan French, K. 1996. Multifactor Explanations of Asset Pricing Anomalies. Journal of Finance. Vol. 51 No.1. Pp: 55-84.

Ferrer, E., Salaber, J., and Zalewska, A. 2016. Consumer Confidence Indices and Stock Markets' Meltdowns. The European Journal of Finance. Vol. 22. Pp: 195-220.

French, J. 2017. Asset Pricing with Investor Sentiment: On the Use of Investor Group Behavior to Forecast ASEAN Markets. Research in International Business and Finance. Vol. 42. Pp: 124148.

Friedman, M. 1953. Essay in Positive Economics. USA: The University of Chicago.

Fisher, K., and Statman, M. 2000. Investor Sentiment and Stock Returns. Financial Analysts Journal. Vol. 56 No. 2. Pp. 16-23.

Fisher, K. L., and Statman, M. 2003. Consumer Confidence and Stock Returns. The Journal of Portfolio Management. Vol. 30 No. 1. Pp: 115-127.

Giacomini, E. 2012. The Role of Investor Sentiment in the Real Estate Market $1^{\text {st }}$ edition. Italy: Eum Edizioni Universita Di Macerata Centro Direzionale.

Groves, R.M. 1989. Survey Errors and Survey Costs. New York: Wiley.

Hoque, H.A.A.B., Kim, J.H, and Pyun, C.S. 2007. A Comparison of Variance Ratio Tests of Random Walk: A Case of Asian Emerging Stock Markets. International Review of Economics and Finance. Vol.16 No. 4. Pp: 488-502.

Huang, C., Yang, X., and Sheng, H. 2014. An Empirical Study of The Effect of Investor Sentiment on Returns of Different Industries. Mathematical Problems in Engineering. Pp: 1-11.

Jansen, W., and Nahuis, N. J. 2003. The Stock Market and Consumer Confidence: European Evidence. Economics Letters. Vol. 79 No. 1. Pp: 89-98.

Jegadeesh, N., and Titman, S. 1993. Returns to Buying Winners and Selling Losers: Implications for Stock Market Efficiency. The Journal of Finance. Vol. 48 No. 1. Pp: 65-91.

Keynes, J.M. 1936. The General Theory of Employment, Interest and Money. Nature. Vol. 137 No. 3471. Pp: 761-762.

Kim, J.H., and Shamsuddin, A. 2008. Are Asian Stock Markets Efficient? Evidence from New Multiple Variance Ratio Tests. Journal of Empirical Finance. Vol. 15 No. 3. Pp: 518-532.

Lam, C.H., and Hui, E.C.M. 2018. How Does Investor Sentiment Predict the Future Real Estate Returns of Residential Property in Hong Kong?. Habitat International. Vol. 75. Pp: 111.

Lao, J, Nie, H., and Jiang, Y. 2018. Revisiting the Investor Sentiment-stock Returns Relationship: A Multi-Scale Perspective Using Wavelets. Physica A: Statistical Mechanics and its Applications. Vol. 499. Pp: 420-427.

Lemmon, M., and Portniaguina, E. 2006. Consumer Confidence and Asset Prices: Some Empirical Evidence. Review of Financial Studies. Vol. 19 No. 4. Pp: 1499-1529.

Litzenberg, R., and Ramaswamy, K. 1979. The Effect of Personal Taxes and Dividends on Capital Asset Prices: Theory and Empirical Evidence. Journal of Financial Economics. Vol. 7. Pp: 163-195

Molchanov, A., and Stangl. J, 2013. Investor Sentiment and Industry Returns. New Zealand: Finance Colloqium.

Nisbett, R.E., and Ross, L. 1980. Human Inference: Strategies and Shortcomings of Social Judgement. Englewoods Cliffs, NJ: Prentice Hall.

Pixley, J. 2002. Expectations, Emotions and Money: Finance Organizations and Futures, in S.R. Clegg (ed.). Management and Organization Paradoxes. Amsterdam: John Benjamins.

Rossenberg, B, Reid, K, and Lanstein, R. 1985. Persuasive Evidence of Market Inefficiency. Journal of Portofolio Management. Vol. 11. Pp. 9-17.

Sayim, M, Morris, P.D, and Rahman, H. The Effect of US Individual Investor Sentiment on IndustrySpecific Stock Returns and Volatility. Review of Behavioral Finance. Vol. 5 No. 1. Pp: 58-76.

Sekkat, M., and Valjamets, H. 2016. Investor Sentiment: An empirical study on Swedish Industries. Tesis. Department of Economics Lund University.

Shiller, R.J. 1981. Do Stock Prices Move Too Much to be Justified by Subsequent Changes in Dividends?. Vol. 71 No. 3. Pp. 421-436.

Shiller, R.J. 2015. Irrational Exuberance: Revised and Expanded $3^{\text {rd }}$ Edition. UK: Princeton University Press. 
Shleifer, A., and Vishny, R.W. 1997. A Survey of Corporate Governance. Vol. 52 No. 2. Pp: 1-43.

Shleifer, A. 2000. Inefficient Markets: An Introduction to Behavioral Finance. USA: Oxford University Press. Inc.

Xu, Y., and Green, C.J. 2012. Asset Pricing with Investor Sentiment: Evidence from Chinese Stock Markets. The Manchester School Journal. Vol. 81 No. 1. Pp: 1-32.

Zafar, B. 2008. An Experimental Investigation of Why Individuals Conform. Federal Reserve Bank of New York Staff Report 365. Available at http://ssrn.com/ abstract=1346428.

Zhang, C. 2008. Defining, Modeling, and Measuring Investor Sentiment. Tesis. Berkeley: Department of Economics University of California. 